\title{
Alternaria Genus and the Diseases Caused to Agricultural and Horticultural Plants
}

\author{
Antonia FLOREA $^{1 *}$, Carmen PUIA ${ }^{1}$ \\ ${ }^{1}$ Faculty of Agriculture, University of Agricultural Sciences and Veterinary Medicine of Cluj-Napoca, Calea Mănăștur \\ 3-5, 400372 Cluj-Napoca, Romania \\ *corresponding author: antonia-luminita.florea@usamvcluj.ro
}

Bulletin UASVM series Agriculture 77(2) / 2020

Print ISSN 1843-5246; Electronic ISSN 1843-5386

DOI:10.15835/buasvmcn-agr: 2020.0034

\begin{abstract}
This work is a bibliographic approach to the historical and most recent taxonomy on Alternaria genus. The genus Alternaria consists largely of species of saprophytic, endophytic and parasitic fungi. The United States Fungal host index ranks the genus Alternaria on the 10th place based on the number of host plants, with over 4,000 species. Govind et al. (2016) tells us that most species of this genus are missing the sexual form, with the exception of a few species, which have, in addition to the anamorphic form, the telemorphic form. With the discovery of several species and due to the superficiality of past research, the inclusion of this genus in the taxonomy has become problematic. At the beginning, the taxonomic classification was performed according to the morphology of the species. This bibliographic approach wants to clarify some of the aspects concerning the old and actual taxonomy ambiguities of Alternaria genus. The method used is consulting the scientific literature. The present reclassification of the species was performed by analysing the DNA of each species in 2013 by Woudenberg et al. and fit the Alternaria species in 25 sections. In 2016 Lawrence et al. added 2 other sections and in 2019 Ghafri et al. forms a new section based on the new species Alternaria omanensis. In conclusion Alternaria genus is now divided in 28 sections, each section contains species that are genetically related. Even though most of the ambiguities have been clarified at present, there are still ambiguities regarding the species within and between sections.
\end{abstract}

Keywords: Alternaria, ambiguities, taxonomy

\section{INTRODUCTION}

The genus Alternaria is largely composed of species of saprophytic, endophytic and parasitic fungi (Lawrence et al., 2016; Singh et al., 2016). According to the taxonomic classification, it belongs to the kingdom of Fungi, the Ascomycota branch, the Pezizomycotina sub-branch, the class Dothideomycetes, the subclass Pleosporales and the family Pleosporaceae (Stuart et al., 2009; Lawrence et al., 2016, Ghafri et al., 2019). The database of the United States of America Fungal host index ranks the genus Alternaria on the 10th position based on the number of host plants, with over 4000 species (Singh et al., 2016). Most species of this genus are devoid of the sexual form (except for a few species, which have in addition the telemorphic form) (Lawrence et al., 2016). With the discovery of several species and due to the superficiality of past research, the inclusion of this genus in taxonomy has become problematic. At the beginning, the taxonomic classification was performed according to the morphology of the species and currently, the reclassification of the species was performed by analysing the DNA of each species (Lawrence 
et al., 2016; Tralamazza et al., 2018; Woudenberg et al., 2013). The damages produced on the crops are significant, with tomatoes registering losses between $50-86 \%$. In addition to crop losses, the spores produce pneumonia, asthma, or sinus irritation (Cruz et al., 2016; Lawrence et al., 2016; Shyama and Somnath, 2015). Some species of the genus Alternaria release mycotoxins in the organs of the attacked plants. Mycotoxins are toxic substances that result due to the pathogen's metabolism. The main mycotoxins produced are: alternariol, alternariol monomethyl ether, altertoxins I, II, III and tenuazonic acid (Pinto and Patriarca, 2017; Tralamazza et al., 2018; Van de Perre et al., 2015). These mycotoxins were found both in raw products (apples, citrus, wheat, tomatoes, sunflower seeds) and in processed products, which come from infected plants. Mycotoxins have a negative effect on human health. They can contribute to chromosomal mutations and affect the integrity of DNA in colon cells (Ostry, 2008; Pinto and Patriarch, 2017; Tralamazza et al., 2018).

The history of the taxonomic classification and the current classification of the Alternaria genus

The history of taxonomic classification has gone through five main stages since 1816, the last revision being made between 2003 and 2015 . The first stage was between 1816 and 1850 and includes the description of the Alternaria tenuis (Lawrence et al., 2016; Pryor and Gilbertson, 2000; Ghafri et al., 2019). During this period, a connection was observed between the anamorphic forms of four genera: Ulocladium, Macrosporium, Alternaria and Brachycladium. In 1833 the genus Stemphylium was added. Because of the ambiguity of the first four genera, they were always confused. Few of the species investigated had been validated. Meanwhile, the genera Brachycladium and Ulocladium had been forgotten (Lawrence et al., 2016, 2013).

The second stage was between 1850 and 1930 . This period was marked by the discovery of new species. About 400 species had been classified, most of them were placed in Macrosporium genus (Singh et al., 2016; Lawrence etal., 2016). After this period, the first taxonomic hierarchy was known by the name of Alternaria and Macrosporium. Most species were distributed according to the morphological characteristics of the conidia like: shape, form, size, colour etc. (Nabahat et al., 2020) and six main groups were formed (Lawrence et al., 2016).

The third stage was between 1930 and 1960 . During this period, an attempt was made to separate the two genera to determine the classification of the genus Stemphylium. The year 1933 was a decisive one, because the researchers came to the conclusion that the genus Macrosporium should be called "nomen ambiguum" (Singh et al., 2016; Lawrence et al., 2016, 2013). This decision was based on the fact that problems occurred because of the numerous taxons that were superficially investigated, and more than 400 fake species were described (Nishikawa and Nakishima, 2020). This conclusion was not immediately accepted. Thus, in 1945, Neergaard (Singh et al., 2016; Lawrence et al., 2016) tried to redistribute them, based on the morphological characteristics of the conidia formation. This classification does not follow the rules of nomenclature and it is not used (Lawrence et al., 2016; 2013).

The fourth stage was between 1960-2000. This stage was dedicated to the researcher Enoy Guy Simmons, who put together all the known information about the Alternaria genus (Lawrence et al., 2016; Pryor B.M. and L. Gilbertson, 2000). During this period, the genus Alternaria and other similar species were called "phaeodictyosporic hypfomycetes", trying to name species with berry shape conidia appearance and dark brown spores imperfect fungi. This category includes the genera Alternaria, Macrosporium and Stemphylium until 1970. Meanwhile, the genus Ulocladium was forgotten and the differentiation between the other three genera was confusing (Lawrence et al., 2016; Pryor and Gilbertson, 2000). The genus Macrosporium was forgotten mainly through the declaration of the species Macrosporium cheiranthi belonging to the Alternaria genus. Later, other genera emerged from the Alternaria genus, such as Alternariaster, Chalastospora, Embellisia, Nimbya and Teretispora (Singh et al., 2016; Lawrence et al., 2016; 2013).

The fifth stage was between 2003-2015, when the reclassification of the genus Alternaria and other related species, through DNA analysis was elaborated.Thefirstapproach of thiswasperformed on the genus Stemphylium and Ulocladium. Studies have revealed a very close relationship between these genera and the Alternaria genus. Due to 
the multitude of morphological characters, DNA sequencing was a good approach to solve some phylogenetic problems by reducing the number of allied genera under Alternaria name (Gannibal and Lawrence, 2018; Lawrence et al., 2016, Nishikawa and Nakishima, 2020). Even though these methods have advanced a lot in the research of this genus, the discrepancy, the relationship between species and the relationship between taxonomy and plant parasitism has not been sufficient to help the practical recognition of species (Nishikawa and Nakishima, 2020). Currently, 28 sections have been formed within the genus based on phylogenetic relationships (Gannibal, 2018; Gannibal and Lawrence, 2018; 2016; Lawrence et al., 2016; Tralamazza et al., 2018; Singh et al., 2016).

Causes of Alternaria ambiguities: morphology of the genus Alternaria, biological cycle and the lack of sexual reproduction

One of the main reasons for Alternaria genus ambiguities is the similarity between the morphological characteristics of the species. The mycelium of the Alternaria genus is composed of conidiophores and conidia (Singh et al., 2016; Lawrence et al., 2016). The conidiophores can be simple or branched, pale brown, grey, dark brown or olive and can be either solitary or grouped in bundles. The surface of the conidia can be smooth or rough, with or without septa. The mycelium is found on the plant on the necrotic lesion (Singh et al., 2016; Stuart et al., 2009, $\mathrm{Hu}$ et al., 2015; Lawrence et al., 2016; Melo et al., 2009; Pinto and Patriarca, 2017; Tralamazza et al., 2018).

Another reason behind these ambiguities is the biological cycle and sexual reproduction. The species of the genus can be parasitic, saprophytic and endophytic. The main categories that cause significant damage are parasites and saprophytes (Lawrence et al., 2016). In order for pathogens to produce infections, the climate must be alternately humid and dry. The optimum temperature of development is between $25-31^{\circ} \mathrm{C}$ and the relative humidity between $70-80 \%$. In case of favourable climatic conditions, the infection occurs within 5-18 hours while the first symptoms appear in 4-6 days (Mamgain et al., 2013; Singh et al., 2016). The penetration occurs through the stomata or healthy tissue and it is favoured by the presence of existing lesions. Once the infection is present, the pathogen releases in plant toxins that can sensitize healthy tissues. The pathogenic mycelium is found mainly on the surface of the affected tissue, along with the conidia. Conidia are usually transported by wind, water, animals, machinery, insects, etc. Spores, which reach other plants or other organs, cause secondary infections. Asexual reproduction is predominant, but there are species that also have a sexual form. Sexual reproduction occurs after 1-2 cycles of asexual reproduction. However, the sexual form was performed only in laboratory conditions because it is hard to reproduce the weather conditions for a long period of time (Meng et al., 2015). The main causes for the lack of sexual multiplication are the changes of the heterothallic system in the homothallic system or the beginning or non-completion of the sexual multiplication cycle (Lawrence et al., 2016; Meng et al., 2015).

\section{Current branching of the Alternaria genus}

The Alternaria genus is divided into 28 sections. Each section includes the species based on morphological and DNA analysis (Table 1).

The main diseases caused by Alternaria spp. to agricultural and horticultural crops

Early blight of potato caused by Alternaria solani, Alternaria protenta, Alternaria linariae, Alternaria grandis

Main symptoms appear on the main organs of the plant: leaves, stem and tuber. The attack on the foliar system is highlighted by the appearance of brown-blackish, circular spots, small at the beginning of the infection but which can increase over time (Fig. 1).

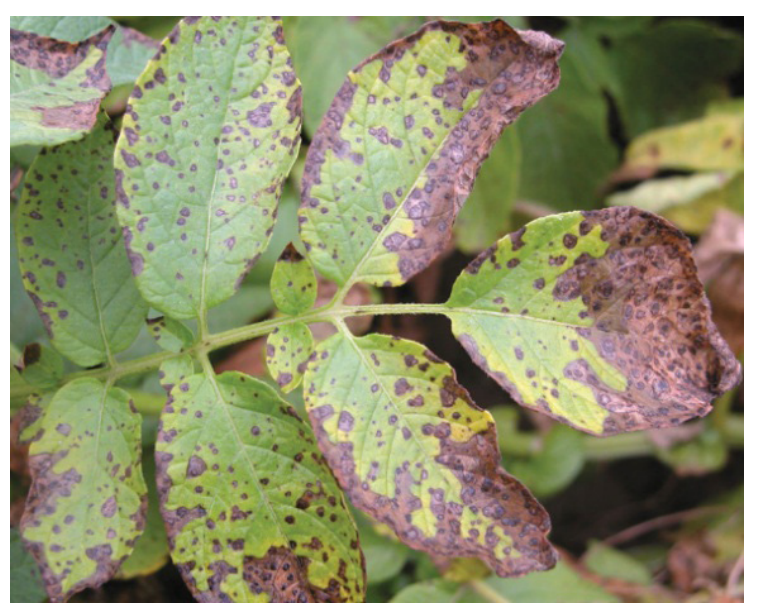

Figure 1. Early blight of potato (http://omafra.gov. on.ca/IPM/english/potatoes/diseases-and-disorders/ alternaria.html) 
Table 1. The sections and species of Alternaria genus based on pylogenetic and morphological analysis.

\begin{tabular}{|c|c|c|}
\hline Section of Alternaria genus & Species & Author \\
\hline Alternantherae & $\begin{array}{l}\text { Alternaria alternantherae, } \\
\text { Alternaria celosiicola } \\
\text { Alternaria gonphenae } \\
\text { Alternaria perpunctulata }\end{array}$ & $\begin{array}{l}\text { Lawrence et al., } 2016 \\
\text { Woudenberg et al., } 2013\end{array}$ \\
\hline Alternaria & $\begin{array}{l}\text { Alternaria arborescens } \\
\text { Alternaria angustiovoidea } \\
\text { Alternaria gaisen } \\
\text { Alternaria alternata } \\
\text { Alternaria burnsii } \\
\text { Alternaria cerealis } \\
\text { Alternaria citriarbusti } \\
\text { Alternaria alstroemeriae } \\
\text { Alternaria betae-kenyensis } \\
\text { Alternaria gossypina } \\
\text { Alternaria iridiaustralis } \\
\text { Alternaria citrimacularis } \\
\text { Alternaria colombiana } \\
\text { Alternaria destruens } \\
\text { Alternaria dumosa } \\
\text { Alternaria herbiphorbicola } \\
\text { Alternaria daucifolli } \\
\text { Alternaria limoniasperae } \\
\text { Alternaria longipes } \\
\text { Alternaria perangusta } \\
\text { Alternaria postmessia } \\
\text { Alternaria tangelonis } \\
\text { Alternaria tomato } \\
\text { Alternaria toxicogenica } \\
\text { Alternaria turkisafria }\end{array}$ & $\begin{array}{l}\text { Paul et al., } 2015 \\
\text { Woudenberg et al., 2013,2014, } 2015\end{array}$ \\
\hline Brassicicola & $\begin{array}{l}\text { Alternaria brassicicola } \\
\text { Alternaria conoidea } \\
\text { Alternaria mimicula } \\
\text { Alternaria septorioides } \\
\text { Alternaria solidaccana }\end{array}$ & $\begin{array}{l}\text { Lawrence et al., } 2016 \\
\text { Woudenberg et al., } 2013\end{array}$ \\
\hline Chalatospora & $\begin{array}{l}\text { Alternaria abundans } \\
\text { Alternaria armoraciae } \\
\text { Alternaria breviramosa } \\
\text { Alternaria malorum } \\
\text { Alternaria cetera } \\
\text { Alternaria obclavata }\end{array}$ & Woudenberg et al., 2013 \\
\hline Cheiranthus & $\begin{array}{l}\text { Alternaria indefessa } \\
\text { Alternaria cheiranthi }\end{array}$ & $\begin{array}{l}\text { Lawrence et al., } 2016 \\
\text { Woudenberg et al., } 2013\end{array}$ \\
\hline Crivellia & $\begin{array}{l}\text { Alternaria papavericola } \\
\text { Alternaria penicillata }\end{array}$ & Woudenberg et al., 2013 \\
\hline Dianthicola & $\begin{array}{l}\text { Alternaria elegans } \\
\text { Alternaria simsimi } \\
\text { Alternaria dianthicola } \\
\end{array}$ & $\begin{array}{l}\text { Lawrence et al., } 2016 \\
\text { Woudenberg et al., } 2013\end{array}$ \\
\hline Embellisa & $\begin{array}{l}\text { Alternaria embellisa } \\
\text { Alternaria tellustris } \\
\text { Alternaria chlamydosporigena. }\end{array}$ & $\begin{array}{l}\text { Lawrence et al., } 2016 \\
\text { Woudenberg et al., } 2013\end{array}$ \\
\hline
\end{tabular}




\begin{tabular}{|c|c|c|}
\hline Embellisioides & $\begin{array}{l}\text { Alternaria botryospora } \\
\text { Alternaria planifunda } \\
\text { Alternaria tumida } \\
\text { Alternaria proteae } \\
\text { Alternaria lolii } \\
\text { Alternaria hyacinthi }\end{array}$ & $\begin{array}{l}\text { Lawrence et al., } 2016 \\
\text { Woudenberg et al., } 2013\end{array}$ \\
\hline Euphorbiicola & $\begin{array}{l}\text { Alternaria limicola } \\
\text { Alternaria euphorbicola. }\end{array}$ & Woudenberg et al., 2014 \\
\hline Eureka & $\begin{array}{l}\text { Alternaria cucumi } \\
\text { Alternaria trigochinicola } \\
\text { Alternaria anigozanthi } \\
\text { Alternaria geniostomatis } \\
\text { Alternaria leptinellae } \\
\text { Alternaria eureka }\end{array}$ & $\begin{array}{l}\text { Lawrence et al., } 2016 \\
\text { Woudenberg et al., } 2013\end{array}$ \\
\hline Gypsophilae & $\begin{array}{l}\text { Alternaria ellipsoidea } \\
\text { Alternaria vaccariae, } \\
\text { Alternaria vaccariicola } \\
\text { Alternaria nobilis } \\
\text { Alternaria saponariae, } \\
\text { Alternaria axiaeriisporifera } \\
\text { Alternaria juxtiseptata } \\
\text { Alternaria gypsophylae }\end{array}$ & $\begin{array}{l}\text { Lawrence et al., 2016, } 2013 \\
\text { Woudenberg et al., } 2013\end{array}$ \\
\hline Infectoriae & $\begin{array}{l}\text { Alternaria grsminicola } \\
\text { Alternaria arbusti } \\
\text { Alternaria caespitose } \\
\text { Alternaria californica } \\
\text { Alternaria conjuncta } \\
\text { Alternaria daucicaulis } \\
\text { Alternaria ethzedia } \\
\text { Alternaria fumenti } \\
\text { Alternaria graminicola } \\
\text { Alternaria hordeiaustralica } \\
\text { Alternaria hordeicola } \\
\text { Alternaria humuli } \\
\text { Alternaria incomplexa } \\
\text { Alternaria alternarina } \\
\text { Alternaria triticina } \\
\text { Alternaria metachromatica } \\
\text { Alternaria infectoria } \\
\text { Alternaria intercpta } \\
\text { Alternaria merytae } \\
\text { Alternaria novae-zelandiae } \\
\text { Alternaria oregonensis } \\
\text { Alternaria slovaca } \\
\text { Alternaria triticimaculans } \\
\text { Alternaria ventricosa } \\
\text { Alternaria viburni }\end{array}$ & $\begin{array}{l}\text { Lawrence et al., } 2016 \\
\text { Woudenberg et al., } 2013\end{array}$ \\
\hline Japonicae & $\begin{array}{l}\text { Alternaria nepalensis } \\
\text { Alternaria japonica } \\
\text { Alternaria telliensis }\end{array}$ & \\
\hline Nimbya & $\begin{array}{l}\text { Alternaria caricis } \\
\text { Alternaria juncicola } \\
\text { Alternaria heteroschemos } \\
\text { Alternaria scirpivora } \\
\text { Alternaria scirpinfestans } \\
\text { Alternaria scirpicola }\end{array}$ & $\begin{array}{l}\text { Lawrence et al., 2012, } 2016 \\
\text { Woudenberg et al., } 2013 \\
\text { Gannibal, } 2018\end{array}$ \\
\hline Omanenses & Alternaria omanenses & Ghafri et al., 2019 \\
\hline
\end{tabular}




\begin{tabular}{|c|c|c|}
\hline Panax & $\begin{array}{l}\text { Alternaria araliae } \\
\text { Alternaria avenicola } \\
\text { Alternaria hedjaroudei } \\
\text { Alternaria calycipyricola } \\
\text { Alternaria dendropanacis } \\
\text { Alternaria photistica } \\
\text { Alternaria eryngii } \\
\text { Alternaria panacis }\end{array}$ & $\begin{array}{l}\text { Lawrence et al., } 2016 \\
\text { Woudenberg et al., } 2013 \\
\text { Hashemlou et al., } 2020\end{array}$ \\
\hline Phragmosporeae & $\begin{array}{l}\text { Alternaria chlamydospora } \\
\text { Alternaria didymospora } \\
\text { Alternaria limaciformis } \\
\text { Alternaria molesta } \\
\text { Alternaria mouchaccae } \\
\text { Alternaria phragmospora }\end{array}$ & $\begin{array}{l}\text { Lawrence et al., } 2016 \\
\text { Woudenberg et al., } 2013\end{array}$ \\
\hline Porri & $\begin{array}{l}\text { Alternaria capsici } \\
\text { Alternaria agerati } \\
\text { Alternaria acalyphicola } \\
\text { Alternaria anagallidis } \\
\text { Alternaria aragakii } \\
\text { Alternaria argyroxiphii } \\
\text { Alternaria bataticola } \\
\text { Alternaria blumeae } \\
\text { Alternaria calendulae } \\
\text { Alternaria carthami } \\
\text { Alternaria cassia } \\
\text { Alternaria cichorii } \\
\text { Alternaria cirsinoxia } \\
\text { Alternaria crassa } \\
\text { Alternaria cretica } \\
\text { Alternaria cyphomandrae } \\
\text { Alternaria cucumerina } \\
\text { Alternaria dauci } \\
\text { Alternaria danida } \\
\text { Alternaria dichondrae } \\
\text { Alternaria grandis } \\
\text { Alternaria hawaiiensis } \\
\text { Alternaria solani } \\
\text { Alternaria linariae } \\
\text { Alternaria limicola } \\
\text { Alternaria linicola } \\
\text { Alternaria macrospora } \\
\text { Alternaria multirostrata } \\
\text { Alternaria passiflorae } \\
\text { Alternaria poonensis } \\
\text { Alternaria porri } \\
\text { Alternaria protenta } \\
\text { Alternaria pseudorostrata } \\
\text { Alternaria pseudorostrata } \\
\text { Alternaria rahapontici } \\
\text { Alternaria scorzonerae } \\
\text { Alternaria sesame } \\
\text { Alternaria solani-nigri } \\
\text { Alternaria steviae } \\
\text { Alternaria subcylindrica } \\
\text { Alternaria zinnia }\end{array}$ & $\begin{array}{l}\text { Barreto et al., } 2008 \\
\text { Gannibal, } 2015 \\
\text { Lawrence } \text { et al., } 2016 \\
\text { Soylu et al., } 2005 \\
\text { Woudenberg et al., 2013,2014 } \\
\text { Gannibal, } 2018\end{array}$ \\
\hline Pseudoalternaria & $\begin{array}{l}\text { Alternaria arrhenatheri } \\
\text { Alternaria rose }\end{array}$ & $\begin{array}{l}\text { Gannibal and Lawrence, } 2016 \\
\text { Lawrence et al., } 2016\end{array}$ \\
\hline
\end{tabular}




\begin{tabular}{|c|c|c|}
\hline Pseudoulocladium & $\begin{array}{l}\text { Alternaria aspera } \\
\text { Alternaria septospora } \\
\text { Alternaria lanuginose } \\
\text { Alternaria sylvestris } \\
\text { Alternaria concatenata } \\
\text { Alternaria chartarum }\end{array}$ & $\begin{array}{l}\text { Lawrence et al., } 2016 \\
\text { Woudenberg et al., } 2013\end{array}$ \\
\hline Radicina & $\begin{array}{l}\text { Alternaria selini } \\
\text { Alternaria petroselini } \\
\text { Alternaria smyrnii } \\
\text { Alternaria carotiiniculatae } \\
\text { Alternaria radicina } \\
\end{array}$ & $\begin{array}{l}\text { Lawrence et al., } 2016 \\
\text { Woudenberg et al., } 2013\end{array}$ \\
\hline Soda & $\begin{array}{l}\text { Alternaria petuchovskii } \\
\text { Alternaria shukurtzii } \\
\text { Alternaria kulundii. }\end{array}$ & Lawrence et al., 2016 \\
\hline Sonchi & $\begin{array}{l}\text { Alternaria sonchi } \\
\text { Alternaria cinerariae }\end{array}$ & Woudenberg et al., 2013 \\
\hline Teretispora & Alternaria leucanthemi & $\begin{array}{l}\text { Lawrence et al., } 2016 \\
\text { Woudenberg et al., } 2013\end{array}$ \\
\hline Ulocladioides & $\begin{array}{l}\text { Alternaria cucurbitae } \\
\text { Alternaria alii-tuberosi } \\
\text { Alternaria castaneae } \\
\text { Alternaria gpagarwalii } \\
\text { Alternaria microspore } \\
\text { Alternaria oblongo-obovoidea } \\
\text { Alternaria populicola } \\
\text { Alternaria preussii } \\
\text { Alternaria pseudobotrytis } \\
\text { Alternaria sorghi } \\
\text { Alternaria zantedeschiae } \\
\text { Alternaria brassicae-pekinensis } \\
\text { Alternaria cantlous } \\
\text { Alternaria consortialis } \\
\text { Alternaria heterospora } \\
\text { Alternaria obovoidea } \\
\text { Alternaria subcucurbitae } \\
\text { Alternaria multiforimis } \\
\text { Alternaria terricola } \\
\text { Alternaria atra }\end{array}$ & $\begin{array}{l}\text { Lawrence et al., } 2016 \\
\text { Woudenberg et al., } 2013 \\
\text { Gannibal et al., } 2018\end{array}$ \\
\hline Ulocladium & $\begin{array}{l}\text { Alternaria capsici-annui } \\
\text { Alternaria botrytis } \\
\text { Alternaria alternariae } \\
\text { Alternaria manihoticola } \\
\text { Altenaria oudemansii }\end{array}$ & $\begin{array}{l}\text { Lawrence et al., } 2016 \\
\text { Woudenberg et al., } 2013 \\
\text { Gannibal et al., } 2018\end{array}$ \\
\hline Undifilum & $\begin{array}{l}\text { Alternaria bornmuelleri } \\
\text { Alternaria cinerea } \\
\text { Alternaria fulva } \\
\text { Alternaria oxytropis }\end{array}$ & Woudenberg et al., 2013 \\
\hline
\end{tabular}

Concentric circles can be seen on the surface of the strains (Waals et al., 2001; Bobes, 1983). On the upper part of the spots appears a black brown down composed of the conidiophores and conidia of the pathogen. As the pathogen develops, the spots on the leaf surface increase and unite leading to the necrosis of the tissue (Bobes, 1983). The attack on the potato tubers can be observed by the presence of dark-brown circular spots, hard in texture and slightly deep into tissue. On their surface there is a black rot formed by the conidia on the conidiophores of the fungus. At first, the 
attack can be seen on the lower floor of the plant then it gradually develops and takes over the plant (Waals et al., 2001; Popescu, 1993).

Alternaria black spot of canola caused Alternaria brassicae Saccardo

The pathogen prefers high temperatures, high humidity, but also the presence of precipitation that favours their development. Main symptoms appear on all green organs. Circular or ellipsoidal spots with a diameter between 2-10 mm appear first on the leaves. The spots are yellowish-black, and concentric formations appear inside them (Singh et al., 2016; Kumar et al., 2014; Bobeș, 1983). On the stem, lesions appear from the top to the base, the spots are elongated in the form of stripes, in the direction of the axis. On the silique, there are a multitude of small spots in size that have the shape of black dots or stripes slightly immersed in the tissue (Singh et al., 2016; Bobes, 1983). As the pathogen develops, the spots join together and form irregular spots. The pathogen grows on the surface of the spots, forming a blackish-brown down composed of the conidia and conidiophores of the fungus (Singh et al., 2016; Bobeș, 1983; Kumar et al. 2015).

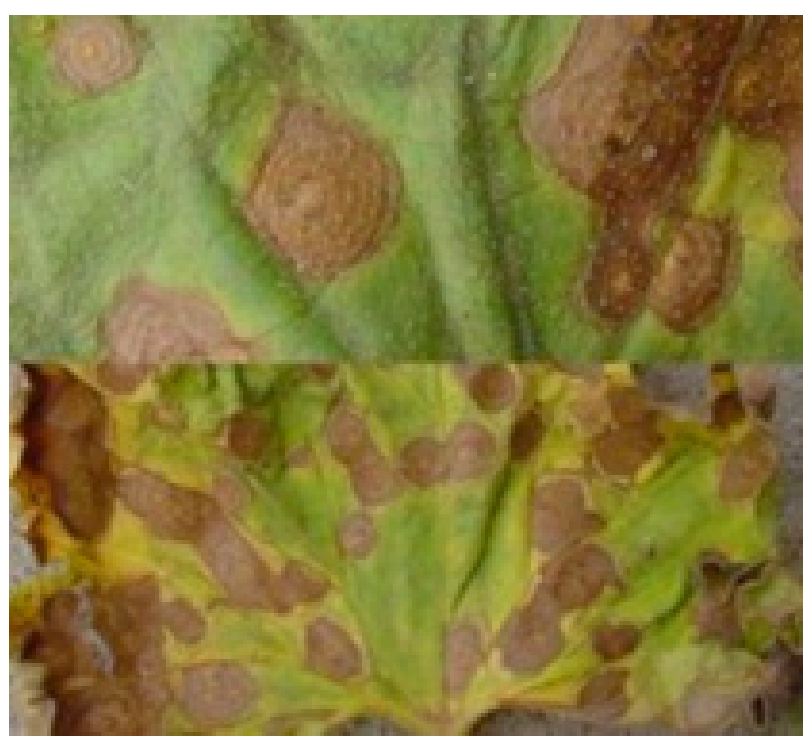

Figure 2. Alternariosis in cucurbits (https://pestre. ro/blog/bolile-castravetilor/)

Alternaria leaf spot of cucurbits caused by Alternaria cucumerina Ellis \& Everhart

The pathogen attacks all the green organs of the plant: leaves, stem and fruits. The spots that appeared at the beginning of the infection are at that moment small in size but with their development can reach up to a diameter of $10 \mathrm{~mm}$ (Yacoub, 2003). The shape of the spots is elliptical, they have a yellow-brown colour, and the spots on the fruit have an aqueous appearance (Fig. 2). As the spots grow, they come together and can cover the entire leaves, causing burns on the stems. On stems and shoots, the affected plants show deep spots and the browning of the tissue (Yacoub, 2003; Bobes, 1983).

Black carrot rot caused by Alternaria radicina Meier, Drechsler \& E.D. Eddy

The disease can occur in all stages of plant development. At the base of leaves, there can be seen an atrophy of the corner that darkens, and the plants wither and fall. The leaves begin to yellow and ultimately suffer drying processes (Scott and Wenham, 1972). In the roots section appear black spots that are deep in the tissue. The edges of the spots can be angular or smooth and are well defined. On the surface of the spots appears the mycelium of the pathogen formed by the conidia and conidiophores of the fungus, with a velvety appearance. It often affects the inside of the root, rarely the top of the root (Farrar et al., 2004; Scott and Wenham, 1972).

Alternariosis of carrot leaves caused by Alternaria dauci Groves \& Skolko

The symptoms of this pathogen can be easily confused with the attack of Cercospora carotae. The leaves that are in a very advanced stage of the attack have spots with necrotic appearance of black-brown colour, surrounded by a chlorothic halo (Scott and Wenham, 1972; Boedo et al., 2010).

Brown spot leaves, stems and calatidium on sunflower caused by $A$. helianthi Tsubaki and Nisihara, Alternaria zinnia Ellis, A. alternata Keissler

Favourable climatic factors for the development and spread of the pathogen are high temperatures above $24^{\circ} \mathrm{C}$ and high humidity. The optimal humidity conditions where the pathogen causes the infection are created after long-term precipitation in the interval of 12-24 hours. The days before the precipitations, in which the temperatures are high and the humidity is low for long periods, stop the development of the disease (Van der Westhuizeni et al., 1980; Baicu et al., 1996). The symptoms are manifested on all the green organs of the plant. Circular or angular brown-grey spots appear on the foliar apparatus, the edge of the spots being 
delimited by a yellow halo. The stains can reach a diameter of $50 \mathrm{~mm}$. On the calatidium and bracts, the spots have a circular appearance. The formed achenes are small in size and dry (Udayashankar et al., 2012; Baicu et al., 1996).

Leaf blight on wheat caused by Alternaria triticina Prasada \& Prabhu

The disease was reported in tropical and subtropical countries, especially in the countries of South and Southeast Asia, by Prasada and Prabhua in 1962 (Vergnes et al., 2006). It prefers areas with warm climates and high temperatures. The first symptoms appear in wheat after 7-8 weeks, evolving with the growth of the plant. The attack can be manifested on all the above-ground organs: leaves, stems, ear, jokes, pale and seed. On the leaf surface, ovoid spots appear, irregular at the beginning, of small dimensions, scattered on the entire leaf surface. As the disease progresses the spots increase in diameter and intertwine (Siddiqui, 2007; Vergnes et al., 2006).

Black spot on carnations caused by Alternaria dianthi Stevens \& Hall and Alternaria dianthicola Neergard

The organs attacked by the pathogen are: leaves, stems and shoots, but attacks on flowers are rare. On the leaves and nodes brown-grey spots appear, well delimited by a portion of healthy tissue, forming a yellow-green halo. When the humidity is high, the spots are covered by the mycelium of the black fungus (Mehta et al., 2007; Popescu, 1993). The attacked leaves fall from the stems and on the shoots the mycelium appears in the form of a ring surrounding the stem. The stems break very easily above the affected area. On the flowers, brown areas are observed on the white petals and discoloration spots on the carnations with red flowers, this symptom being characteristic of the A. dianthicola (Popescu, 1993).

Saffron alternariosis caused by Alternaria carthami S. Chowdhury

The attack of the pathogen is observed on the foliar apparatus of the plant by the presence of small spots, circular or with irregular edge, brown colour, and on their edges, light green halos are present. As the attack progresses, the spots intertwine and enlarge. On the surface of the spots appears a blackish mycelium consisting of conidiophores and conidia of the pathogen (Ivaşcu et al., 2009).

\section{CONCLUSION}

Currently, the last attempt to taxonomically reclassify the genus Alternaria was made between 2003 and 2015, where due to modern technologies; the species was identified by molecular analysis. However, the differences between the species of the different sections are still unknown. On the territory of Russia, interactions of species from different sections of the genus Alternaria have been found on plants from the Solanacae family (Kokaeva et al., 2017; Lawrence et al., 2016).

Acknowledgments. This research did not receive any specific grant from funding agencies in the public, commercial, or not-for-profit sectors.

\section{REFERENCES}

1. Armitage AD, Cockerton HM, Sreenivasaprasad S, Woodhall J, Lane CR, Harrison RJ, Clarkson JP (2020). Genomics evolutionary history and diagnostics of the Alternaria alternata species group including apple and asian pear pathotypes. Frontiers in Microbiology, 10: 3124.

2. Baicu T, Tatiana Eugenia ȘT (1996). Fitopatologie Agricolă. Ed. Ceres, București.

3. Barreto RW, Santin AM, Vieira BS (2008). Alternaria cichorii in Brazil on Cichorium spp. seeds and cultivated and weedy hosts. Journal of Phytopathology, 156: 425430.

4. Bobes I (1983). Atlas de fitopatologie și protecția agroecosistemelor. Ed.Ceres, București.

5. Boedo C, Berruyer R, Lecomte M, Bersihand S, Briard M, Le Clerc V, Simoneaua P, Pouparda P (2010). Evaluation of different methods for the characterization of carrot resistance to the Alternaria leaf blight pathogen (Alternaria dauci) revealed two qualitatively different resistances. Plant Pathology, 59: 368-375.

6. Comes T, Lazar A, Bobeș I, Hatman M, Drăcea A (1982). Fitopatologie, Ed. Didactică și Pedagogică. București.

7. Cruz CRM, Laforet EP, Oyarzo PV, Silva LC (2016). Identificación de Alternaria botrytis (preuss) Woudenberg y Crous. Revista Argentina de Microbiología, 48: 182-183.

8. Farrar JJ, Pryor BM, Davis RM (2004). Alternaria Diseases of Carrot. Plant Disease, 88(8): 776-784.

9. Gannibal PB (2015). Distribution of Alternaria species among sections. 1. Section Porri. Mycotaxon, 130: 207213.

10. Gannibal PB (2016). Distribution of Alternaria species among sections. 2. Section Alternaria. Mycotaxon, 130: 941-949.

11. Gannibal PB (2018). Distribution of Alternaria species among sections. 4. Species formerly assigned to genus Nimbya. Mycotaxon, 133: 37-43. 
12. Gannibal PB, Lawrence DP (2016). Distribution of Alternaria species among sections. 3. Sections Infectoriae and Pseudoalternaria. Mycotaxon, 131: 781-790.

13. Gannibal PB, Lawrence DP (2018). Distribution of Alternaria species among sections. 5. Species producing conidia with many longitudinal septa. Mycotaxon, 133: 285-291.

14. Gannibal PB, Lawrence DP (2018). Distribution of Alternaria species among sections. 6. Species formerly assigned to genus Ulocladium. Mycotaxon, 133: 293-299.

15. Ghafri AA, Maharachchikumbura SNS, Hyde KD, Al-Saady $\mathrm{N}, \mathrm{Al}$-Saady AM (2019). A new section and a new species of Alternaria encountered from Oman. Phytotaxa, 405(6): 279-289.

16. Govind SS, Naresh MP, Dayal M (2016). Alternaria diseases of crucifers: biology, ecology and disease management, Springer, DOI 10.1007/978-981-10-0021-8.

17. Hashemlou E, Ghosta Y, Poursafar A, Azizi R (2020). Morphological and molecular identification of Alternaria hedjaroudei sp. nov., a new species in section Panax from Iran. Phytotaxa, 438 (2): 130-140.

18. Hu W, Ran Y, Zhuang K, Lama J, Zhang C (2015). Alternaria arborescens infection in a healthy individual and literature review of cutaneous alternariosis. Mycopathologia, 179: 147-152.

19. Ivaşcu A, Simion J-G, Vasile E (2009). Ghid pentru determinarea rezistenţei la boli și dăunători. Biroului de calcul al I.S.T.I.S.

20. Kokaeva LY, Belosokhov AF, Doeva LY, Skolotneva ES, Elansky SN (2017). Distribution of Alternaria species on blighted potato and tomato leaves in Russia. Journal of Plant Diseases and Protection, 125: 205-212.

21. Kumar D, Maurya N, Bharati YK, Kumar A, Kumar K, Srivastava K, Chand G, Kushwaha C, Singh SK, Mishra RK, Kumar A (2014). Alternaria blight of oilseed Brassicas: A comprehensive review. African Journal of Microbiology Research, 8 (30): 2816-2829.

22. Lawrence DP, Rotondo F, Gannibal PB (2016). Biodiversity and taxonomy of the pleomorphic genus Alternaria. Mycological Progress, 15: 3.

23. Lawrence DP, Park M, Pryor BM (2012). Nimbya and Embellisia revisited, with nov. comb for Alternaria celosiae and A. perpunctulata. Mycological Progress, 11: 799-815.

24. Lawrence DP, Gannibal PB, Peever TL, Pryor BM (2013). The sections of Alternaria: formalizing species-group concepts. Mycologia, 105: 530-546.

25. Mamgain A, Roychowdhury R, Tah J (2013). Review Alternaria pathogenicity and its strategic controls. Research Journal of Biology, 1: 1-9.

26. Mehta R, Sharma S, Nath AK (2007). In vitro selection and biochemical characterization of carnation (Diathus caryophyllus) Callus culture tolerant to Alternaria dianthi. Indian Journal Plant Physiol., 12 (2):120-126.

27. Melo MP, Soares DJ, Araújo JSP, Tostes GO (2009). Alternaria leaf spot, caused by Alternaria thunbergiae, recorded for the first time on Thunbergia alata from Brazil. Australasian Plant Disease Notes, 4: 23-25.
28. Meng JW, Wen Z, Han HM, Wu EJ, Duan GH, Xie YK, Jin Y, Li N, Shang L, Zhan J (2015). Population genetic analysis reveals cryptic sex in the phytopathogenic fungus Alternaria alternate. Scientific Reports, 5:18250.

29. Nabahat B, Bruno H, Simoneau NB, Kihal M, Simoneau P (2020). Alternaria telliensis sp. nov., a new species isolated from Solanaceae in Algeria. Phytotaxa, 440 (2): 089-100.

30. Nishikawa J, Nakishima C (2020). Japanese species of Alternaria and their species boundaries based on host range. Fungal Systematics and Evolution, 5: 197-281.

31. Ostry V (2008). Alternaria mycotoxins: an overview of chemical characterization, producers, toxicity, analysis and occurrence in foodstuffs. World Mycotoxin Journal, 1:175-188.

32. Paul NC, Deng JX, Lee HB, Yu SH (2015). Characterization and pathogenicity of Alternaria burnsii from seeds of Cucurbita maxima (Cucurbitaceae) in Bangladesh. Mycobiology, 43: 384-391.

33. Pinto VEF, Patriarca A (2017). Alternaria species and their associated mycotoxins, mycotoxigenic fungi: Methods and Protocols, Methods in Molecular Biology. Springer New York, Vol. 1542.

34. Popescu G (1993). Fitopatologie. Ed. Tehnică, București

35. Pryor BM, Gilbertson L (2000). Molecular phylogenetic relationships amongst Alternaria species and related fungi based upon analysis of nuclear ITS and $\mathrm{mt}$ SSU rDNA sequences. Mycological Research, 104 (11): 1312-1321.

36. Scott DJ, Wenham HT (1972). Occurrence of two seedhorne pathogens Alternaria radicina and Alternaria dauci, on imported carrot seed in New Zealand. New Zealand Journal of Agricultural Research, 16: 247- 250.

37. Shyama S, Somnath K (2015). Evaluation of culture media for growth characteristics of Alternaria solani, causing early blight of tomato. Journal of Plant Pathology and Microbiology, 1: 5.

38. Siddiqui ZA (2007). Biocontrol of Alternaria triticina by plant growth promoting rhizobacteria on wheat, Archives of Phytopathology and Plant Protection, 40(4): $301-308$.

39. Singh SG, Mehta N, Meena PD (2016). Alternaria diseases of crucifers: biology, ecology and disease management. Springer, Singapore.

40. Soylu S, Kurt S, Soylu EM, Tok FM (2005). First report of Alternaria leaf blight caused by Alternaria dauci on carrot in Turkey. Plant Pathology, 54: 252-252.

41. Stuart RM, Bastianel M, de Azevedo FA, Machado MA (2009). Alternaria Brown Spot. Fitopatologia, 30: 29-44.

42. Tralamazza SM, Piacentini KC, Iwase CHT, Rocha LO (2018). Toxigenic Alternaria species: impact in cereals worldwide. Current opinion in food science, 23: 57-63.

43. Udayashankar AC, Chandra NS, Archana B., Anjana G, Niranjana SR, Mortensen CN, Lund OS, Prakash HS (2012). Specific PCR-based detection of Alternaria helianthi: the cause of blight and leaf spot in sunflower. Archives of Microbiology, 194: 923-932.

44. Van de Perre E, Jacxsens L, Liu C, Devlieghere F, Meulenaer B (2015). Climate impact on Alternaria moulds and their mycotoxins in fresh produce: The case of the tomato chain. Food Research International, 68: 41-46. 
45. Van der Westhuizeni GCA, Holtzhausen MA (1980). Alternaria helianthi on sunflower in South Africa. Phytophylactica, 12: 49-52.

46. Vergnes MD, Renard ME, Duveiller E, Maraite H (2006). Identification of Alternaria spp. on wheat by pathogenicity assays and sequencing. Plant Pathology, 55: 485-493.

47. Waals der var JE, Korsten L, Aveling TAS (2001). A review of early blight of potato. African Plant Protection, 7(2): 91-102.

48. Woudenberg JHC, Groenewald JZ, Binder M, Crous PW (2013). Alternaria redefined. Studies in Mycology, 75: 171-212.

49. Woudenberg JHC, Truter M., Groenewald JZ, Crous PW (2014). Large spored Alternaria pathogens in section Porri disentangled. Studies in Mycology, 79: 1-47.
50. Woudenberg JHC, Seidl MF, Groenewald JZ, de Vries M, Stielow JB, Thomma BPHJ, Crous PW (2015). Alternaria section Alternaria: Species, formae speciales or pathotypes? Studies in mycology, 82: 1-21.

51. Yacoub B (2003). Alternaria leaf spot disease on Cucumber: Susceptibility and control using leaf disk assay. An-Najah University Journal Research, 17(2): 269-279.

52. ***, http://omafra.gov.on.ca/IPM/english/potatoes/ diseases-and-disorders/alternaria.html Accessed 09.11.2020

53. ***, https://pestre.ro/blog/bolile-castravetilor/ Accessed 09.11.2020 